\title{
PERALATAN INFORMASI DAN NORMALISATOR PH AIR BERBASIS IOT UNTUK MENJAGA PRODUKTIVITAS/ PERTUMBUHAN SPIRULINA SP
}

\author{
Dzulfikar Johan Akbar', Mochammad Adiel Assidiq ${ }^{2}$, Dendy Ary Nugroho ${ }^{3}$, Mas Aldi \\ Putra $^{4}$, Ristha Dewi Budiono 5 , Redyarsa Dharma Bintara ${ }^{6}$ \\ 1,2,3,4,6Program Studi S1 Teknik Mesin, Fakultas Teknik, Universitas Negeri Malang \\ ${ }^{5}$ Program Studi S1 Teknik Elektro, Fakultas Teknik, Universitas Negeri Malang \\ *Email Korespondensi: johanakbar07@gmail.com
}

Submitted : 2 September 2021; Revision : 14 September 2021; Accepted : 2 Oktober 2021

\begin{abstract}
ABSTRAK
Spirulina sp (Arthrospira platensis) merupakan bakteri hijau-biru yang mengandung nutrisi paling ideal bagi umat manusia walau hanya dikonsumsi dalam jumlah kecil. Permasalahan mitra pada budidaya Spirulina $s p$ adalah fluktuasi $\mathrm{pH}$ air pada kolam, sehingga pertumbuhan Spirulina sp kurang baik. Kontrol $\mathrm{pH}$ air dilakukan secara manual dan normalisasi $\mathrm{pH}$ air juga di lakukan secara manual, sehingga sering mengalami keterlambatan informasi dan normalisasi $\mathrm{pH}$ air. Selain itu mitra harus meluangkan waktu lebih banyak di kolam. Dengan kondisi demikian produktifitas hanya mampu memproduksi rata-rata perminggu sebesar 375 gram. Dengan kondisi demikian di perlukan peralatan informasi dan normalisasi $\mathrm{pH}$ air berbasis Internet of Thinks (IoT) untuk menjaga produktifitas Spirulina $s p$. Metode yang di gunakan adalah perencanaan, pembuatan dan evaluasi kinerja peralatan informasi dan normalisasi $\mathrm{pH}$ air berbasis IoT pada mitra. Dari program ini dihasilkan peralatan Informasi $\mathrm{pH}$ air dan normalisasi $\mathrm{pH}$ air dapat dilakukan secara real time dan dapat dilakukan dari mana saja, sehingga mitra dapat beraktivitas di luar kolam Spirulina sp. Selain itu terdapat peningkatan produktivitas Spirulina $s p$ perminggu dari rata-rata sebesar 375 gram menjadi rata-rata sebesar 511.5 gram.
\end{abstract}

Kata kunci: Spirulina sp , pH air, Produktifitas.

\begin{abstract}
Spirulina sp (Arthrospira platensis) is a blue-green bacterium that contains the most ideal nutrients for human beings even though it is only consumed in small amounts. Partner problems in Spirulina sp cultivation are fluctuations in the $\mathrm{pH}$ of the water in the pond, so the growth of Spirulina sp is not good. Control of water $\mathrm{pH}$ is done manually and normalization of water $\mathrm{pH}$ is also done manually, so there are often delays in information and normalization of water $p H$. In addition partners should spend more time in the pool. Under these conditions, productivity is only able to produce an average of 375 grams per week. With these conditions, information equipment and Internet of Thing (IoT)-based water pH normalization are needed to maintain the productivity of Spirulina sp. The method used is planning, manufacturing and evaluating the performance of information equipment and normalizing IoT-based water $\mathrm{pH}$ on partners. From this program, information on water $\mathrm{pH}$ and normalization of water $\mathrm{pH}$ can be done in real time and can be done from anywhere, so partners can do activities outside the Spirulina sp. In addition, there was an increase in the productivity of Spirulina sp per week from an average of 375 grams to an average of 511.5 grams.
\end{abstract}

Keywords: Spirulina $\mathrm{sp}$, water $\mathrm{pH}$, productivity.

\section{PENDAHULUAN}

Spirulina sp (Arthrospira platensis) merupakan bakteri hijau-biru yang hayati secara alami pada danau alkali. Spirulina sp sudah dicanangkan oleh World Health Organization (WHO) menjadi kuliner yg mengandung nutrisi yang ideal bagi umat manusia (Hadiyanto and Maulana, 2012; Ulya, Sedjati and Yudiati, 2018). Karena mengandung protein, multivitamin, mineral, asam amino, dan anti oksidan alami. Pada umumnya, produk 
Spirulina $s p$ yg sudah tersebar dipasaran berkecimpung pada bidang suplementasi kuliner $\&$ kosmetik. Hal itu dimungkinkan lantaran Spirulina sp mengandung protein yg jauh lebih tinggi dibandingkan menggunakan daging, ikan, kedelai, susu, telur \& bahan pangan lainnya. Akan tetapi, manfaat berdasarkan produk Spirulina $s p$ hanya terbatas dalam 2 bidang tersebut. Sebagai contoh, Spirulina sp juga bisa dipakai menjadi pakan ternak, agen pengolahan limbah, \& bahkan biofuel. (Christwardana and Nur, 2013). Dalam bidang kesehatan, juga sangat banyak riset dan permintaan agar Spirulina sp dijadikan sebagai suplemen kesehatan karena banyak riset yang membuktikan bahwa Spirulina $s p$ dapat menurunkan kolesterol, mendukung penurunan berat badan, menurunkan tekanan darah, serta meningkatkan metabolisme dalam tubuh. Dalam energi terbarukan, Spirulina $s p$ sering dimanfaatkan dan dikonversi menjadi biomassa. Platensis mengandung senyawa yang diperlukan oleh tubuh manusia diantaranya protein $55-70 \%$, lipid $4-6 \%$, karbohidrat $17-25 \%$, asam lemak tidak jenuh majemuk misalnya asam linoleat (LA) dan gamma linolenat (GLA), beberapa vitamin contohnya asam nikotinat, riboflavin (vitamin B2), thiamin (vitamin B1), sianokobalamin (vitamin B12), mineral, asam-asam amino, karotenoid, klorofil dan fikosianin (Afriani, Uju and Setyaningsih, 2018; Endrawati, Manulang dan Widianingsih, 2012).

Spirulina $s p$ merupakan mikroalga yang menyebar secara luas di alam dan dapat ditemukan di berbagai tipe lingkungan, baik di perairan payau, laut dan tawar (Gouveia, 2003). Mikroalga Spirulina sp . merupakan organisme autotroph berwarna hijau kebiruan terdiri dari sel-sel silindris yang membentuk koloni dimana selnya berkolom membentuk filament terpilin menyerupai spiral (helix) sehingga disebut juga alga biru hijau berfilamen (Hariyati, 2008; Guo, Zhang and Zhao, 2018). Spirulina sp merupakan jenis mikroalga golongan Cyanophyta atau alga hijau biru (blue-green algae) yang telah banyak digunakan sebagai pakan alami dalam usaha budi daya khususnya dalam pembenihan, karena memiliki nilai nutrisi yang tinggi. Kandungan protein Spirulina $s p$ adalah 60-70\% sedangkan kandungan lemak cukup rendah yaitu 1,5-12\% (Ridho and Hartati, 2010).

Nilai $\mathrm{pH}$ merupakan faktor penting bagi pertumbuhan alga hijau biru khususnya Spirulina $s p$. Keadaan asam yang baik untuk pertumbuhan Spirulina $s p$ adalah netral dan lebih mentolerir dalam kondisi basa karena Spirulina sp mampu memanfaatkan karbon dioksida secara efisien walaupun tersedia dalam jumlah yang minim. Spirulina $s p$ mampu menggunakan ion dari sodium bikarbonat sebagai sumber karbon untuk foto sintesis. $\mathrm{pH}$ di bawah 8 atau di atas 10,5 akan menghambat pertumbuhan Spirulina sp , karena akan menyebabkan lisis dan mengubah bentuk pertumbuhan pigmen (Hariyati, 2008).

Pada program PKM-PI ini, mitra yang akan di bantu dalam penyelesaian masalah adalah Verteblue (VB) Spirulina sp Malang. Mitra merupakan sebuah entitas komersial yang bergerak dalam bidang usaha pertanian di wilayah kota Malang dan berdiri pada bulan Oktober 2019. Bisnis ini sudah beroperasi selama setahun, namun VB Spirulina sp baru mulai mengembangkan bisnis pemasarannya pada awal tahun 2020. Perusahaan fokus pada pengembangan makanan mikroalga Spirulina $s p$, pakan ternak dan budi daya kosmetik di daerah perkotaan. Komoditi yang dijual di pasaran antara lain: Spirulina sp Seed Starter Packing, Spirulina sp Dry Treatment Powder, Smiling Guppy Spirulina sp Flakes dan Aneka Masker Spirulina sp.

Verteblue Spirulina $s p$ Malang mengalami beberapa kendala dalam budidaya Spirulina $s p$, yaitu pada stabilitas $\mathrm{pH}$ air. $\mathrm{pH}$ air sebagai media hidup perlu dijaga antara pada $\mathrm{pH} 8$ - 10.5 supaya Spirulina $s p$ dapat tumbuh dengan baik dan produktivitas meningkat. Saat ini Verteblue Spirulina sp Malang memiliki produktivitas sebesar 375 gram dalam bentuk kering setiap minggunya. Untuk meningkatkan produktivitas Spirulina $s p$ dapat dilakukan dengan menjaga $\mathrm{pH}$ air yang dilakukan secara otomatis. Selain itu $\mathrm{pH}$ air juga di harapkan dapat di kontrol dari jarak jauh, sehingga mitra dapat melakukan kegiatan di luar kolam Spirulina $s p$. Dengan demikian mitra membutuhkan peralatan informasi dan normalisator $\mathrm{pH}$ Air berbasis IoT. 


\section{METODE}

Metode kegiatan ini adalah penerapan ipteks kepada mitra yaitu .peralatan informasi dan normalisator $\mathrm{pH}$ Air berbasis IoT untuk meningkatkan produktifitas Spirulina $s p$. Adapun tahapan pelaksanaan kegiatan ini sebagai berikut; tahap pertama adalah perencanaan dengan studi literatur, survey dan analisa keadaan mitra, tahap kedua adalah pembuatan alat dan tahap ketiga adalah evaluasi kinerja alat pada mitra. Pada proses evaluasi kinerja alat pada mitra di lakukan pengujian tanpa dan dengan menggunakan peralatan informasi dan normalisator $\mathrm{pH}$ Air berbasis IoT. Evaluasi ini di harapkan di peroleh dampak produksi pada mitra. Setelah kinerja peralatan di evaluasi kemudian dilakukan pelatihan pemanfaatan dan perawatan pada mitra. Kegiatan tahap pertama hingga tahap ketiga di laksanakan selama 3 bulan, terhitung sejak 7 Juni 2021 - 16 Agustus 2021.

\section{HASIL DAN PEMBAHASAN}

Proses budidaya pada mitra masih menggunakan proses manual yang sederhana dengan menggunakan tenaga manusia dalam pengecekan $\mathrm{pH}$ dan pemberian nutrien, yang tentunya membutuhkan waktu yang lebih lama untuk berada di kolam Spirulina $s p$. Ada beberapa tahap dalam proses pengecekan $\mathrm{pH}$ dan pemberian nutrien, Adapun prosesnya sebagai berikut:

1. Pengecekan $\mathrm{pH}$ oleh mitra menggunakan $\mathrm{pH}$ meter. Pengecekan $\mathrm{pH}$ menggunakan $\mathrm{pH}$ meter ini dilakukan dengan cara mencelupkan $\mathrm{pH}$ meter ke dalam kolam untuk memperoleh nilai $\mathrm{pH}$. Dalam pengecekan dengan metode ini $\mathrm{pH}$ hanya dapat ditentukan dalam akurasi 1 seperti pada Gambar 1.

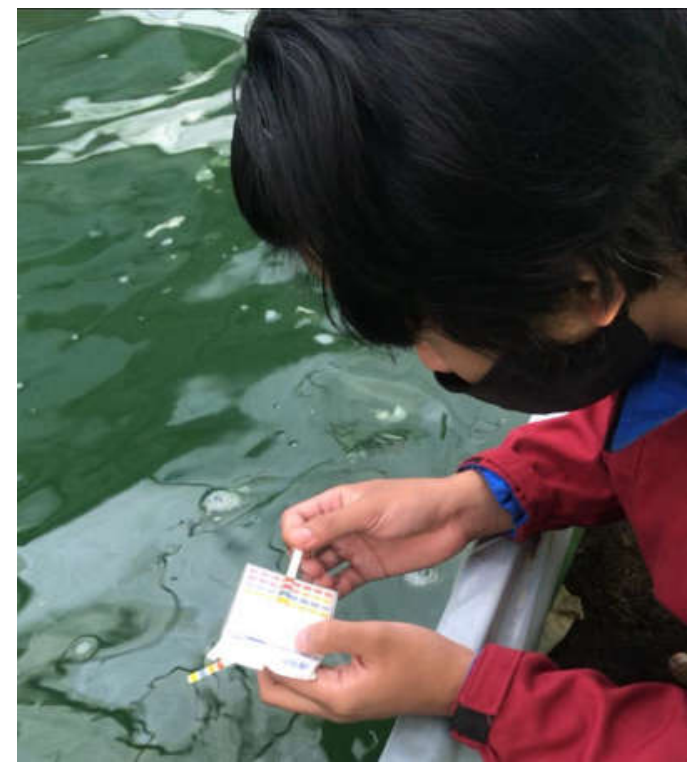

Gambar 1. Pengecekan Nilai pH Pada Kolam Secara Manual

2. Jika $\mathrm{pH}$ pada kolam kurang dari 8.5, maka proses yang harus dilakuan adalah penimbangan sodium bikarbonat dan air. Proses ini dilakukan untuk mendapatkan campuran yang sesuai dengan kebutuhan Spirulina $s p$. Berat sodium yang digunakan adalah 100 gr per 5 liter air.

3. Proses pencampuran air dengan sodium bikarbokat dilakukan secara manual dengan komposisi air 5 liter dan sodium bikarbonat 100 gram, dilakukan secara manual pada wadah plastik dan diaduk hingga merata seperti Gambar 2. 


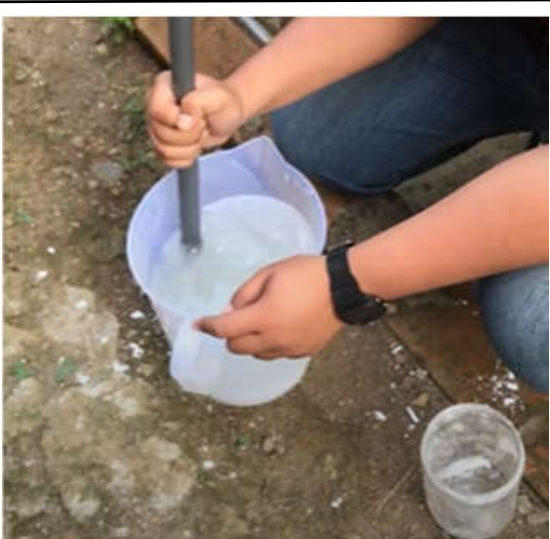

Gambar 2. Pencampuran Air dan Sodium Bikarbonat Secara Manual

4. Pengecekan $\mathrm{pH}$ pada campuran air dan sodium bikarbonat untuk mengetahui apakah campuran tersebut sudah cukup basa dengan nilai minimal 8 untuk diberikan pada Spirulina sp seperti Gambar 3.

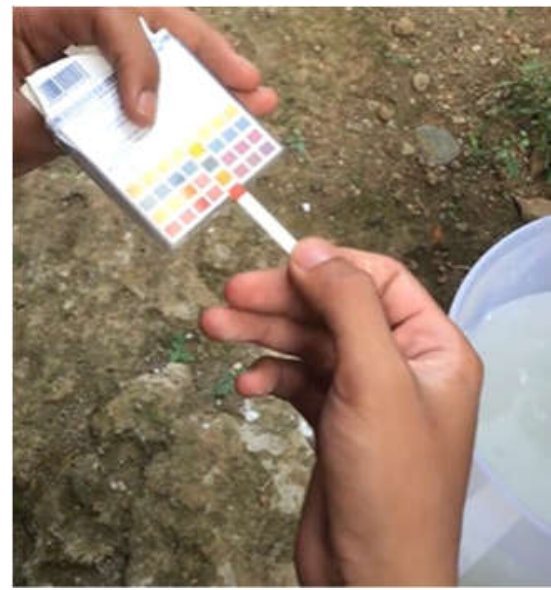

Gambar 3. Pengecekan pH Pada Campuran Air dan Sodium Bikarbonat

5. Pemberian campuran air dan sodium bikarbonat pada Gambar 4 kepada Spirulina $s p$ yang dilakukan secara manual. Proses ini dilakukan agar $\mathrm{pH}$ air kolam tetap terjaga dalam rentang 8,5 hingga 11 (Buwono and Nurhasanah, 2018).

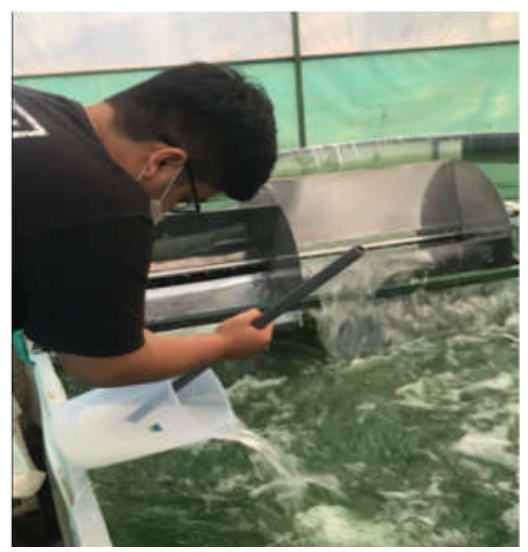

Gambar 4. Pemberian Campuran Air dan Sodium Bikarbonat 
6. Proses normalisasi $\mathrm{pH}$ air perlu dibantu oleh turbin air agar campuran air dan sodium bikarbonat dapat merata seperti Gambar 5.

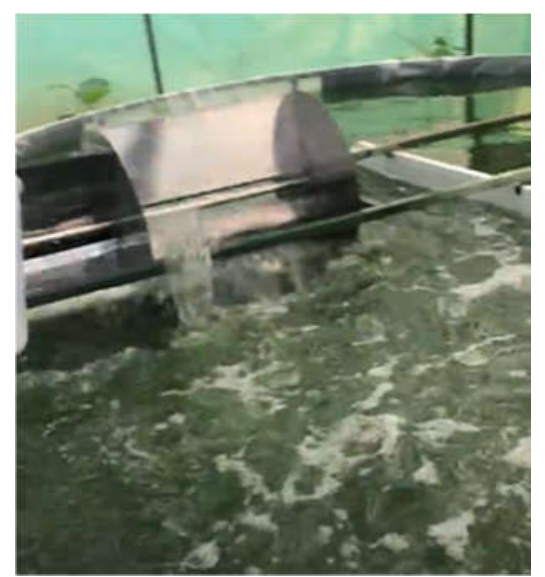

Gambar 5. Turbin Bergerak Mencampur Air, Sodium Bikarbonat dengan Air Kolam

Dari program PKM-PI ini di hasilkan peralatan yang di butuhkan oleh mitra, yaitu peralatan informasi dan normalisator $\mathrm{pH}$ air berbasis IoT. Adapun peralatan sebagai berikut:

1. Peralatan informasi $\mathrm{pH}$ air berbasis IoT. Adapun proses informasi $\mathrm{pH}$ Air sebagai berikut:

a. Sensor $\mathrm{pH}$ akan memberikan data berupa tegangan ke arduino. Jenis arduino yang kami gunakan adalah Arduino Wemos.

b. Dari arduino, data dalam bentuk tegangan diubah menjadi data nilai $\mathrm{pH}$ berupa angka, kemudian di kirim dan di simpan di database.

c. Kemudian dari database di kirim informasi nilai $\mathrm{pH}$ ke smartphone mitra melalui Wifi. Tampilan informasi $\mathrm{pH}$ air, seperti pada Gambar 6.

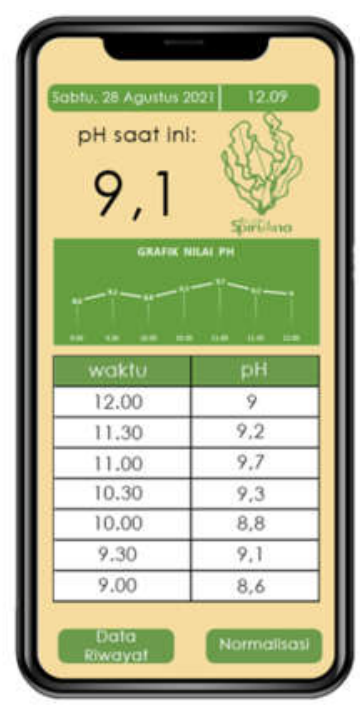

Gambar 6. Tampilan Informasi pH Air Berbasis IoT

2. Peralatan normalisator $\mathrm{pH}$ air berbasis IoT seperti Gambar 7. Adapun proses normalisasi $\mathrm{pH}$ Air sebagai berikut: 
a. Dari smartphone, mitra melakukan proses normalisasi dengan cara mengklik normalisasi pada fitur di smartphone ketika nilai $\mathrm{pH}$ kurang dari angka 8,5.

b. Dari smartphone dikirimkan data untuk melakukan normalisasi ke database melalui Wifi.

c. Software pada database, akan memerintahkan microcontroller untuk membuka valve 1 dan valve 2 .

d. Setelah air dan sodium bikarbonat ditampung pada tabung mixing, maka motor pengaduk akan bekerja.

e. Setelah beberapa saat pengaduk bekerja, kemudian motor akan membuka valve 3 .

f. Selanjutnya campuran air dan sodium bikarbonat akan menuju kolam dan $\mathrm{pH}$ air akan normal kembali setelah Spirulina $s p$ menyerap nutrien dan terjadinya proses kimia.

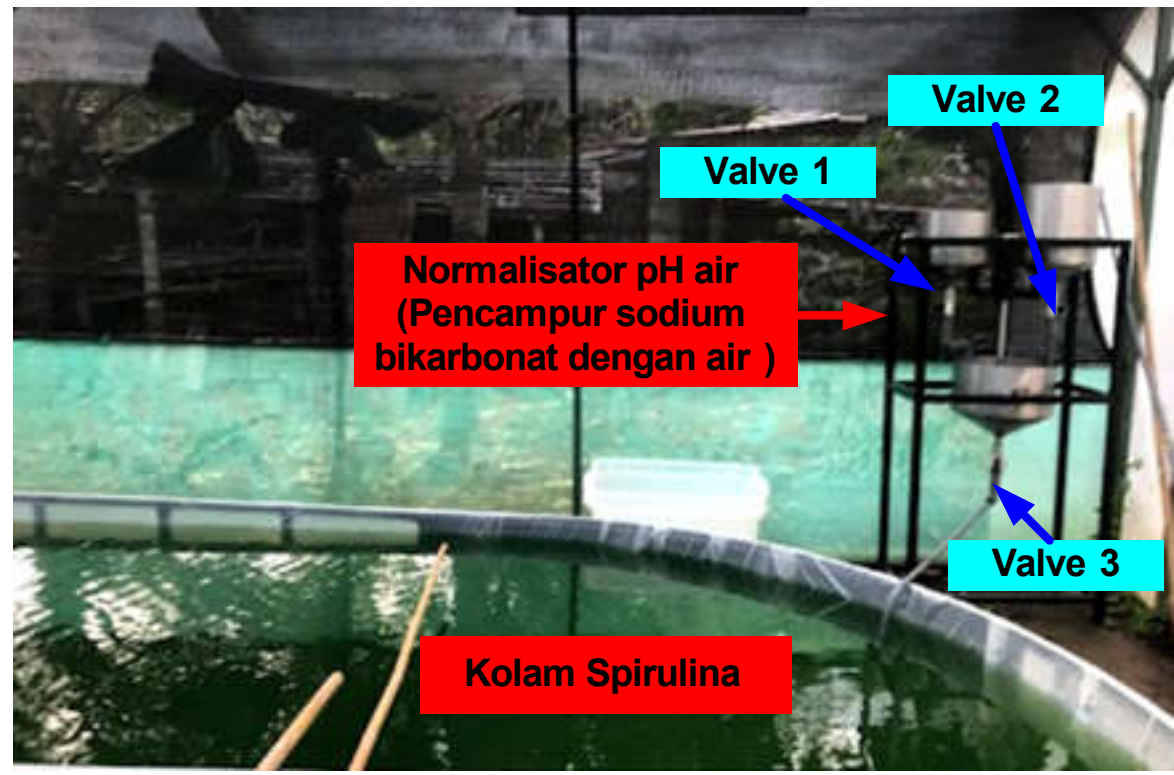

Gambar 7. Normalisator pH Air Berbasis IoT

\section{DAMPAK DAN MANFAAT}

Dengan adanya bantuan teknologi tersebut mitra sangat terbantukan, di mana informasi $\mathrm{pH}$ air dan untuk melakukan normalisasi $\mathrm{pH}$ air dapat di terima secara real time dan dilakukan dari mana saja, sehingga mitra dapat beraktivitas di luar kolam Spirulina sp . Selain itu, hasil evaluasi kinerja alat $\mathrm{pH}$ air menjadikan $\mathrm{pH}$ air dapat terkontrol dengan baik. Evaluasi kinerja alat $\mathrm{pH}$ air dapat di lihat pada Gambar 8 .

Dari grafik tersebut terlihat pada bulan Juni merupakan produktivitas Spirulina $s p$ tanpa peralatan informasi dan normalisasi $\mathrm{pH}$ air berbasis IoT, sedangkan bulan Agustus sudah menggunakan peralatan informasi dan normalisasi $\mathrm{pH}$ air berbasis IoT. Dari grafik tersebut terlihat perbedaan pada setiap minggunya, dimana pada bulan Juni nilai produktivitasnya selalu lebih rendah di bandingkan dengan bulan Agustus. Kondisi demikian di sebabkan oleh $\mathrm{pH}$ air yang stabil, sehingga pertumbuhan Spirulina sp menjadi stabil dan dapat meningkat produktivitas. Dari grafik tersebut, kemudian di rata-rata dan di peroleh produktivitas Spirulina sp rata-rata sebesar 375 gram pada bulan Juni 2021, dan setelah adanya program PKM-PI produktivitas meningkat menjadi rata-rata sebesar 511.5 gram pada bulan Agustus 2021 


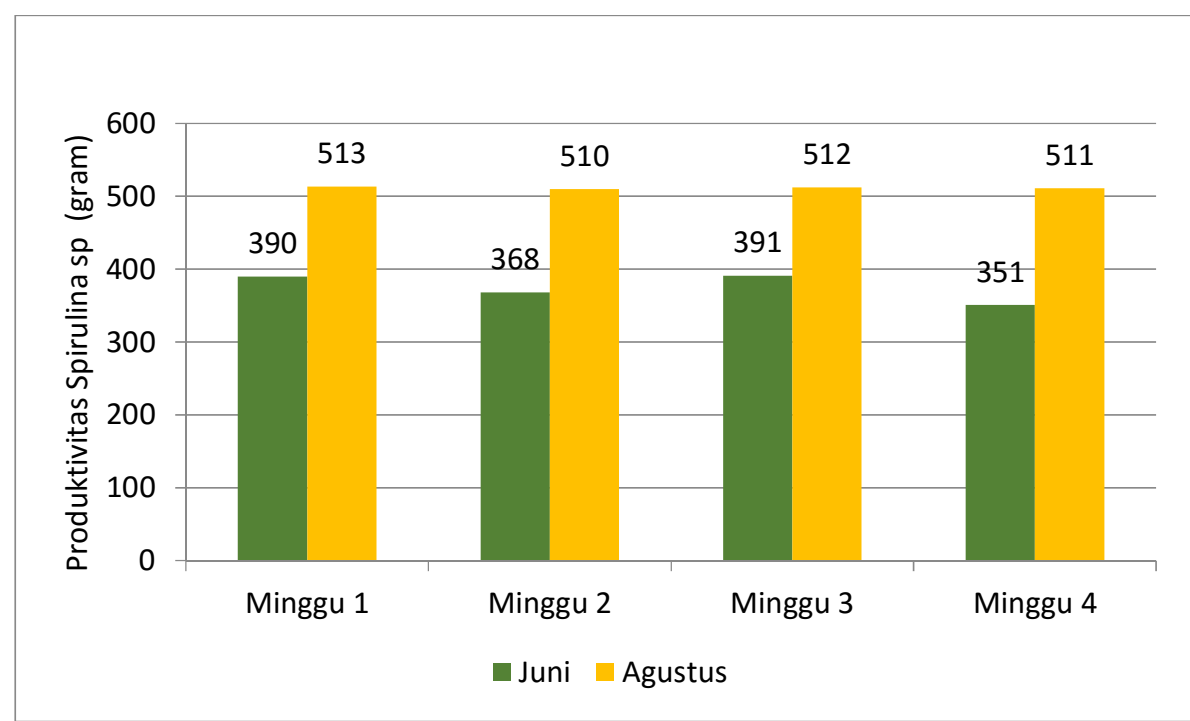

Gambar 8. Grafik Sebelum (Juni) dan Sesudah (Agustus) Menggunakan Peralatan PKM-PI

\section{KESIMPULAN}

Dari program PKM-PI yang dilakukan, dapat di simpulkan, bahwa informasi $\mathrm{pH}$ air dan normalisasi $\mathrm{pH}$ air dapat dilakukan secara real time dan dilakukan dari mana saja, sehingga mitra dapat beraktivitas di luar kolam Spirulina $s p$. Terdapat peningkatan produktivitas Spirulina $s p$ dari rata-rata sebesar 375 gram menjadi rata-rata sebesar 511.5 gram.

\section{UCAPAN TERIMA KASIH}

Terimakasih kepada Kemenristek DIKTI yang telah memdanai kegiatan PKM-PI. Serta Mitra Vertebleue yang sudah bekerja sama dengan tim kami

\section{REFERENSI}

Afriani, S., Uju, dan Setyaningsih, I., (2018). Komposisi Kimia Spirulina sp Platensis yang dikulturtivasi dalam Fotobioreaktor dengan Fotoperiode Berbeda. JPHPI, 21(3),471- 479.

Buwono N.R. and Nurhasanah R.Q., (2018). Studi Pertumbuhan Populasi Spirulina sp . pada Skala Kultur yang Berbeda. Jurnal Ilmiah Perikanan dan Kelautan Vol 10, No 1 .

Christwardana, M., \& Nur, M. M. A. (2013). Spirulina sp platensis: Potensinya sebagai Bahan Pangan Fungsional. Jurnal Aplikasi Teknologi Pangan. 2 (1), 1-4.

Endrawati H., Manulang C., dan Widianingsih., (2012). Densitas dan Kadar Total Lipid Mikroalga Spirulina $s p$ Platensis yang dikultur pada Fotoperioda yang Berbeda. Bull. Osean. Marina. 1, 33-38.

Gouveia, L., Rema, P., Pereira, O., \& Empis, J. (2003). Colouring Ornamental Fish (Cyprinus Carpio and Carassius Auratus) with Microalgal Biomass. In Aquaculture Nutrition. Vol. 9, Issue 2.

Guo, P., Zhang, Y., and Zhao, Y. (2018). Biocapture of $\mathrm{CO}_{2}$ by Different Microalgal-Based Technologies for Biogas Upgrading and Simultaneous Biogas Slurry Purification under Various Light Intensities and Photoperiods. Int. J. Environ. Res. Public 
Health. 15 (3), 528.

Hadiyanto dan Maulana, A. (2012). Mikroalga Sumber Pangan dan Energi Masa Depan. Semarang: UPT UNDIP Press. 1-138.

Hariyati, R. (2008). Pertumbuhan \& Biomassa Spirulina $s p$. dalam Skala Laboratoris. Laboratorium Ekologi \& Biosistematik. BIOMA, 10 (1) : 19-22.

Ridho, W. A., \& Hartati, R. (2010). Kandungan Nutrisi Spirulina sp Platensis yang Dikultur pada Media yang Berbeda. ILMU KELAUTAN: Indonesian Journal of Marine Sciences, 13(3), 167-170.

Ulya, S., Sedjati, S., \& Yudiati, E. (2018). Kandungan Protein Spirulina sp platensis pada Media Kultur dengan Konsentrasi Nitrat (KNO3) yang Berbeda. Buletin Oseonografi Marina, 7(2), 98-102. 
Filename: $\quad 06$ J11 Revisi 2717-7214-1-ED.docx

Directory: $\quad$ C: $\quad$ UUsers $\quad$ hp $\backslash$ Documents

Template: $\quad$ C: $\quad$ Users $\backslash h p \backslash A p p D a t a \backslash$ Roaming $\backslash$ Microsoft $\backslash$ Templates $\backslash$ Normal.dotm

Title:

Subject:

Author:

Keywords:

Comments:

Creation Date: $\quad$ 15-Sep-21 8:31:00 PM

Change Number: 6

Last Saved On: $\quad$ 19-Sep-21 9:35:00 AM

Last Saved By: $\quad$ hp

Total Editing Time: 23 Minutes

Last Printed On: $\quad$ 19-Sep-21 9:35:00 AM

As of Last Complete Printing

Number of Pages: 8

Number of Words: $\quad$ 4,717 (approx.)

Number of Characters: $\quad 26,893$ (approx.) 